\title{
Hematology and recovery response in jacundá, Crenicichla saxatilis (Linnaeus, 1758) after short-term handling stress
}

\author{
By M. de Souza Neves ${ }^{1}$, L. A. L. Barbas ${ }^{2}$ and R. Y. Fujimoto ${ }^{3}$ \\ ${ }^{1}$ Instituto de Estudos Costeiros, Faculdade de Engenharia de Pesca, Bairro Aldeia, Bragança, Pa, Brazil; ${ }^{2}$ Instituto Federal de \\ Educação Ciência e Tecnologia do Pará, Campus Castanhal, Pa, Brazil; ${ }^{3}$ Embrapa Tabuleiros Costeiros, Aracaju, Sergipe, \\ Brazil
}

\section{Summary}

The objective of this study was to evaluate the hematological response of ringtail pike cichlid ornamental fish (Crenicichla saxatilis) during the recovery period after short-term stress. The fish were previously submitted to the stress of chasing, capture and air exposure. Assayed were 24 C. saxatilis $(85.2 \pm 61.6 \mathrm{~g})$ in three groups of eight fish; after $0.5,6$ and $24 \mathrm{~h}$ recovery, blood samples were collected. The total erythrocyte, relative thrombocyte and differential leukocyte counts as well as total hemoglobin, hematocrit, glucose, total plasma protein and the red blood cells (RBC) indices of mean corpuscular volume (MCV), mean corpuscular hemoglobin $(\mathrm{MCH})$ and $\mathrm{MCH}$ concentration $(\mathrm{MCHC})$ were determined. Stress responses were observed after $0.5 \mathrm{~h}$, although hyperglycemia remained constant during the experiment. Total lymphocyte and hemoglobin values decreased after $0.5 \mathrm{~h}$ in the recovery period. An increase of neutrophils and monocytosis was observed after 0.5 and $6 \mathrm{~h}$, respectively. The MCHC remained stable until after $0.5 \mathrm{~h}$, then varied from this time forward. $\mathrm{MCV}, \mathrm{MCH}$ and erythrocyte numbers oscillated throughout the experiment. Intense stress was observed in the studied $C$. saxatilis, with most hematological variables not returning to their initial levels after $24 \mathrm{~h}$.

\section{Introduction}

Crenicichla is the most abundant species genus within the neotropical Cichlidae family (Kullander and Lucena, 2006). The Crenicichla saxatilis species used in this study, popularly known as jacundá or ringtail pike cichlid, has a wide geographical distribution and is commercialized as an ornamental fish around the world. A striking feature of this family is the multicolored and sometimes iridescent skin pattern, which makes it a significant target species in aquaria trade (Gama and Halboth, 2003). There is no data in the scientific literature on the maintenance of this species in captivity.

Handling procedures of fish subjected to fisheries or fish farming can bring about stress. Their capture and transport are considered significant stressors. Fish management by itself is also an inevitable stressor agent in ornamental fish farming and allows the introduction of unwanted variables when erroneously implemented (Barton et al., 2003; Urbinati and Carneiro, 2004). Amazon artisanal fisheries (field observations) use gillnets and trawl nets to capture ornamental fish; the specimens remain within the net for counting and selection, and are then exposed to air in transport until the fisherman returns to shore where the animals are stocked.

Studies on the physiological responses of fish in stress situations are important, as these stress conditions may affect food intake, productive performance and health, thereby increasing their susceptibility to diseases (Val et al., 2006; Upton and Riley, 2012). The responses and consequences of fishes to stress are very complex (Sumpter et al., 1994; Urbinati and Carneiro, 2004). The magnitude of response to stress is species-specific and varies according to the stressor agent, intensity and exposure time (Moraes and Martins, 2004). The set of responses to stress loses its adaptive role and becomes dysfunctional if it remains active for a long period of time, consequently affecting the growth, reproductive competence, and competition for food, as well as the organization of the population, community and ecosystem (Val et al., 2006)

Hematological evaluation has been developed as a way to mitigate the negative effects of stress, since the study of blood components is an important supplier of auxiliary information for determining the diagnosis of disease and/or stress (Ranzani-Paiva and Eiras, 1992). The hematological profile and its responses towards adverse situations such as acute stress in ringtail pike cichlids are unknown. Thus, to identify and understand the responses of this species under short-term handling stress is important to minimize its negative effects and provide a better product quality for the market.

This study aimed to evaluate the hematological response of ringtail pike cichlid during the recovery period of $0.5,6$ and $24 \mathrm{~h}$ after submission to short-term handling stress.

\section{Materials and methods}

Ringtail pike cichlids for this study were caught in Chumucuí River, Bragança, Pará, Brazil (1 $\left.{ }^{\circ} 12^{\prime} 38.3^{\prime \prime} \mathrm{S} ; 4^{\circ} 47^{\prime} 32^{\prime \prime} \mathrm{W}\right)$ during the dry season by hook and line and transported to the laboratory for the experiment. Of the 28 collected fish, four did not survive handling and died within $24 \mathrm{~h}$ after collection. Juvenile fishes $(\mathrm{n}=24)$ with an average weight of $85.2 \pm 61.6 \mathrm{~g}$ and $16 \pm 4.1 \mathrm{~cm}$ (SL) were acclimated in a 
recirculation closed system with $310-\mathrm{L}$ polyethylene tanks, at six fish per tank for 12 days prior to the handling trials. Trial specimens were fed small live fish (collected from the same river) and commercial pellets (32\% crude protein) ad libitum once a day until apparent satiation. Temperature, $\mathrm{pH}$ and dissolved oxygen were monitored daily. After the acclimation period fish were captured by hand nets for the first blood sampling. The entire capture and sampling procedures were performed within two minutes for each fish and the data considered as control values. Blood sampling $(1 \mathrm{ml})$ was conducted in all fishes by puncturing the caudal vessel with a $3 \mathrm{ml}$ syringe and needle moistened with $10 \%$ EDTA. Iodine was used as an antiseptic. After each blood sampling a macroscopic examination of the external structures was conducted to detect possible ectoparasites or injury. Differential leukocyte and thrombocytes counts were done on airdried blood smears and stained by Rosenfeld. Thrombocytes per 100 leukocytes were counted; blood glucose was determined by an automatic measuring device (Prestige ${ }^{\circledR}$ IQ 50), hematocrit by the microhematocrit method, total plasma protein with a refractometer (Quimis ${ }^{\circledR}$ Q667), total erythrocyte count on a Neubauer chamber, and the hemoglobin concentration by the cyanmethemoglobin method. These data allowed determination of the RBC indices: MCV, MCH and MCHC (Vallada, 1999).

To ensure a new situation with either no stress or a minimum thereof, a 14-day recovery period was established, corresponding to twice the number of days reported in studies of acute stress recovery for tropical fish (Takahashi et al., 2006; Mariano et al., 2009). After this period, all fish were subjected to acute handling stress by simulating the same procedures used by artisanal fishermen: (i) two 15-min chases with a hand net using continuous circular movements followed by an interval of $10 \mathrm{~min}$, (ii) capture and 15-min agglomeration in groups of 4 or 5 fish using a hand net, (iii) air exposure in groups of 4 or 5 fish four times for $5 \mathrm{~min}$, with intervals of $10 \mathrm{~min}$.

After the stressor was applied (the sum of time of the aforementioned steps, including intervals), a recovery period at intervals of $0.5,6$ and $24 \mathrm{~h}$ was established and new blood samplings ( $\mathrm{n}=8$ in each interval) were taken for the assessment of hematological responses. Parasitological examinations were performed on any dead fish whereby only a few Monogenea in the gills were observed, ensuring that the cause of mortality was not by parasitical diseases.

Data were analyzed using Bioestat 4.0. The Shapiro-Wilk test for normality and the outlier verification were carried out; any abnormally distributed data were arcsine squareroot transformed. The results were thereafter submitted to analysis of variance. A Tukey test was used for comparison of means at $5 \%$ of probability for values of $F$ with a significant difference $(\mathrm{P}<0.05)$.

\section{Results}

Specimens were maintained in flowing water with dissolved oxygen $\left(5.2 \pm 0.29 \mathrm{mg} \mathrm{L}^{-1}\right), \mathrm{pH}(6.5 \pm 0.26)$ and temperature $\left(28.0 \pm 0.12^{\circ} \mathrm{C}\right)$ values within the range observed in the natural environment.
Table 1

Hematological profile (before handling) in Crenicichla saxatilis. Means and Standard Deviation (SD) Weight, Standard Length, Blood Glucose, Plasma Protein, Hematocrit, Total Hemoglobin, Erythrocytes, MCV, MCH, MCHC, Lymphocytes, Neutrophils, Monocytes, Immature Cells and Thrombocytes, $\mathrm{n}=24$

\begin{tabular}{|c|c|}
\hline Parameter & Mean $\pm \mathrm{SD}$ \\
\hline Weight $(\mathrm{g})$ & $85.2 \pm 61.6$ \\
\hline Standard Length $(\mathrm{cm})$ & $16 \pm 4.1$ \\
\hline Blood Glucose $\left(\mathrm{mg} \mathrm{dl}^{-1}\right)$ & $86.2 \pm 58.2$ \\
\hline Plasma Protein $\left(\mathrm{g} \mathrm{dl}^{-1}\right)$ & $6.6 \pm 0.4$ \\
\hline Hematocrit $(\%)$ & $25.8 \pm 4.8$ \\
\hline Total Hemoglobin $\left(\mathrm{g} \mathrm{dl}^{-1}\right)$ & $8.7 \pm 1.9$ \\
\hline Erythrocytes $\left(\times 10^{6} \mu \mathrm{l}^{-1}\right)$ & $1.0 \pm 0.4$ \\
\hline $\mathrm{MCV}$ (fL) & $316.6 \pm 154.7$ \\
\hline MCH (picog) & $106.4 \pm 54.0$ \\
\hline $\operatorname{MCHC}\left(\mathrm{g} \mathrm{dl}^{-1}\right)$ & $34.1 \pm 6.8$ \\
\hline Lymphocytes (\%) & $97.2 \pm 5.2$ \\
\hline Neutrophils (\%) & $1.8 \pm 2.7$ \\
\hline Monocytes (\%) & $0.4 \pm 1.2$ \\
\hline Immature Cells (\%) & $4.9 \pm 5.5$ \\
\hline Thrombocytes (cel. 100 leuc. $^{-1}$ ) & $7.4 \pm 6.6$ \\
\hline
\end{tabular}

Lymphocytes predominated, followed by neutrophils and monocytes. Basophils, eosinophils and Granulocyte PAS positive (GPAS) were not observed. Presence of erythrocytes, leukocytes and thrombocytes were observed in this sequence. The hematological baseline profile for blood parameters in ringtail pike cichlid is shown in Table 1.

In this study we observed mortality of four, one and eight fishes in the first, second and third blood samplings performed during the recovery period. Hyperglycemia was observed after 0.5 and $6 \mathrm{~h}$ of recovery time (Fig. 1). There was a sharp increase in erythrocytes after $0.5 \mathrm{~h}$, a decrease over $6 \mathrm{~h}$ and the return to initial levels within $24 \mathrm{~h}$ (Fig. 1b). The opposite occurred with MCV and MCH (Fig. 1c,d) where the MCHC decreased after $6 \mathrm{~h}$ and increased within $24 \mathrm{~h}$ (Fig. 1e). Total hemoglobin (Fig. 1f) decreased from $0.5 \mathrm{~h}$ onwards and a decrease in total plasma protein after $6 \mathrm{~h}$ (Fig. 1h).

Jacundá showed lymphocytopenia and neutrophilia (Fig. 2a,b) in $0.5 \mathrm{~h}$ and monocytosis in the leukocyte count within $6 \mathrm{~h}$ of recovery (Fig. 2c). Noteworthy is that leukocytes such as basophils, eosinophils and GPAS were not observed in blood smears.

Weight, standard length (SL), immature cells and thrombocytes did not show significant differences (Table 2).

\section{Discussion}

The control hematological profile in ringtail pike cichlid proved to be qualitatively similar to those of other species mentioned in the literature, with predominant lymphocytes, followed by neutrophils and monocytes and absence of basophil and eosinophil (Tavares-Dias and Faustino, 1998; Tavares-Dias et al., 2000; Ranzani-Paiva et al., 2003; Coffigny et al., 2005). The quantitative cellular values were different from other species such as Oreochromis niloticus and Ramdia quelen, but this was expected due to interspecific variations (Tavares-Dias et al., 2002; Tavares-Dias, 2003). 


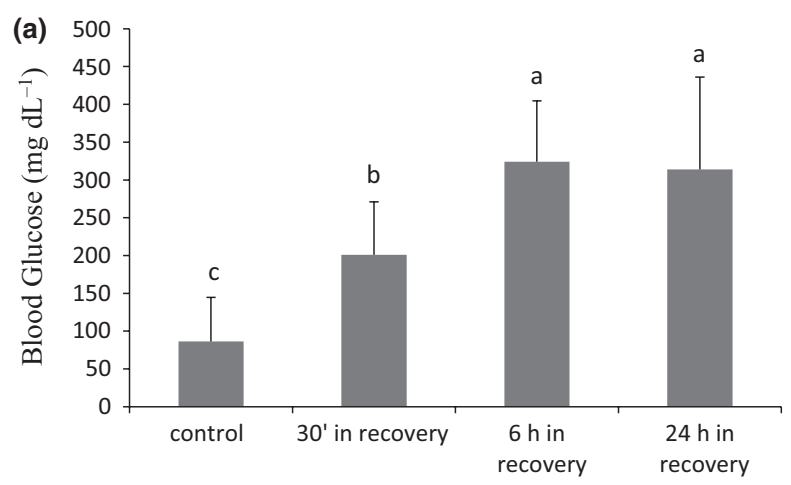

(e)
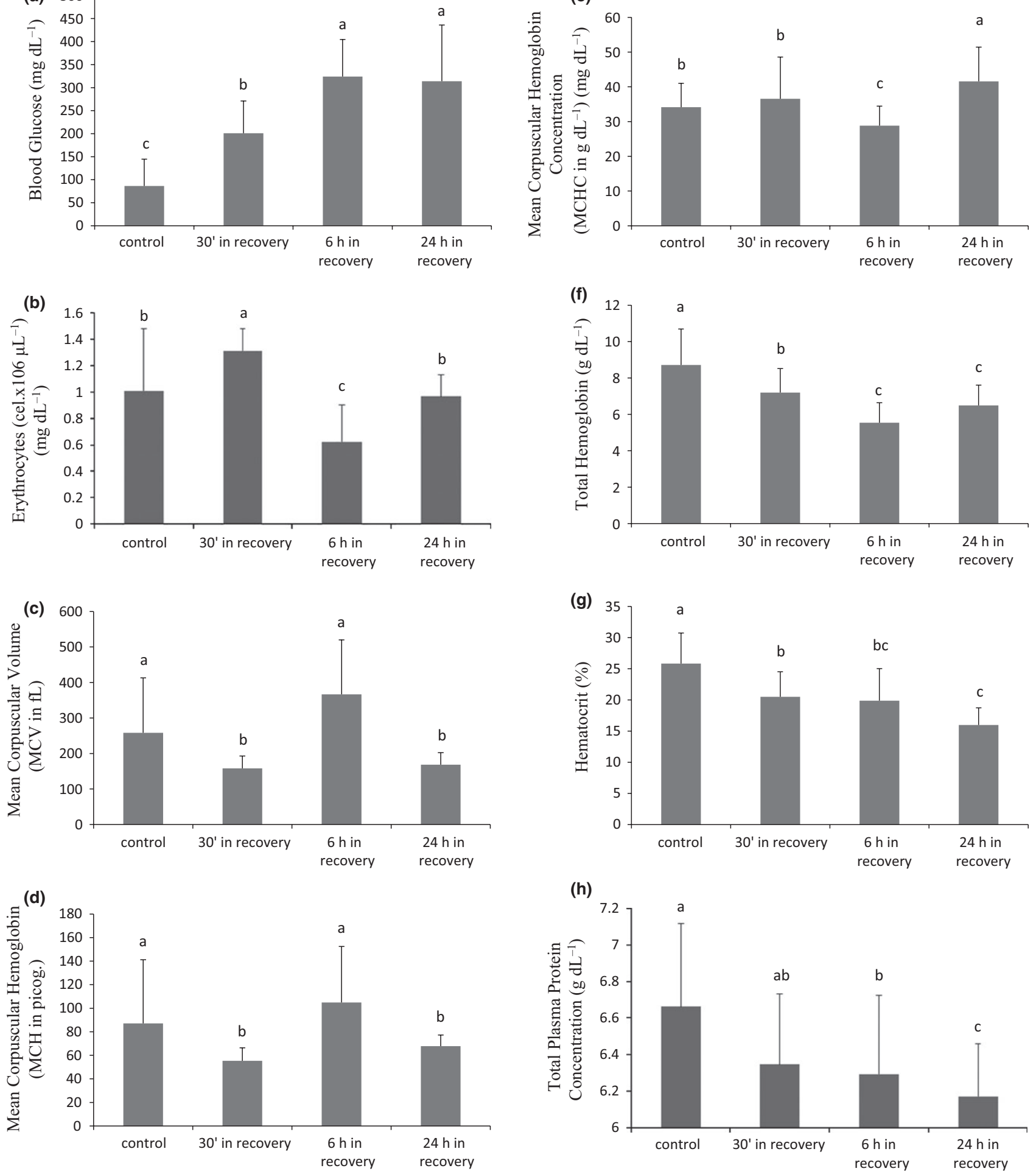

Fig. 1. Hematological profile in Crenicichla saxatilis before and after (in recovery) short-term handling stress. Means and Standard Deviation of (a) Blood Glucose ( $\mathrm{mg} \mathrm{dl}^{-1}$ ) (b) Erythrocytes (cel. $\times 106 \mu \mathrm{l}^{-1}$ ), (c) Mean Corpuscular Volume (MCV in fL); (d) Mean Corpuscular Hemoglobin ( $\mathrm{MCH}$ in picog.), (e) $\mathrm{MCH}$ Concentration $\left(\mathrm{MCHC}\right.$ in $\mathrm{g} \mathrm{dl}^{-1}$ ); (f) Total Hemoglobin ( $\mathrm{g} \mathrm{dl}^{-1}$ ); (g) Hematocrit (\%) and (h) Total Plasma Protein Concentration $\left(\mathrm{g} \mathrm{dl}^{-1}\right)$. Columns with same letter do not differ by Tukey test at $5 \%$ of probability, $\mathrm{n}=24$

However, the blood parameters (Table 1) before stress induction were considered appropriate for fish farming (Ozório et al., 2004).
It is important to note the percentage of thrombocytes (7.4 cel. per 100 Leuc. $^{-1}$ ). Some studies show considerable differences in thrombocyte values, which occur presumably 

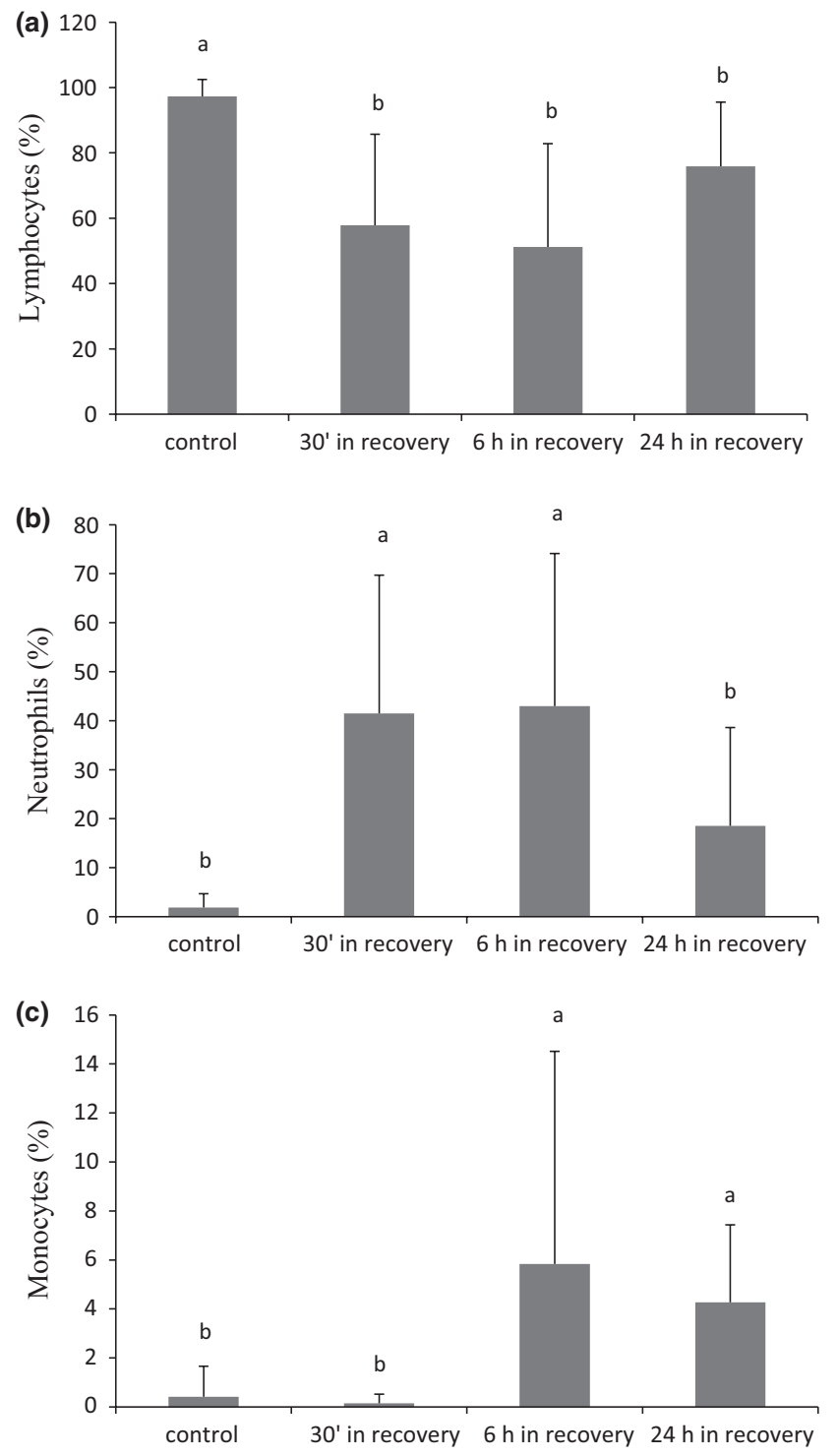

Fig. 2. Leukocyte count in Crenicichla saxatilis before and after (in recovery) short-term handling stress. Means and Standard Deviation values: (a) Lymphocytes (\%) (b) Neutrophils (\%) and (c) Monocytes $(\%)$ of Jacundá before and after being subjected to chasing, capture and air exposure up to $24 \mathrm{~h}$ after stress induction. Columns with same letter do not differ by Tukey test at $5 \%$ of probability, $n=24$

due to the inclusion of these cells in the differential leukocyte count making it difficult for comparison of results. Some researchers justify such an inclusion because of the leuko- cyte-like phagocytic potential of these cells (Tavares-Dias, 2003).

In spite of the similarities it is worth mentioning that hematology in fishes differs both inter - and intraspecifically, and may change according to body size and environmental context (Tavares-Dias et al., 2000, 2002). Other factors associated with differences in hematology are nutritional status, seasonality, gonadal maturation, sex, and genetic variation (Kori-Siakpere, 1985).

After the first blood sampling the most susceptible animals died. Under unfavorable conditions fishes attempt to restore their initial physiological balance in order to survive the threats posed by stress (Urbinati and Carneiro, 2004); in order for this to occur, the body develops a set of organic, physiological and behavioral changes (Barton and Iwama, 1991). However, as the stressor agent exceeds the body adapting capacity, it undergoes a sequence of physiological disturbances that may lead to reduced growth and death, reaching the stage of exhaustion of the General Adaptation Syndrome (GAS) (Selye, 1950). The mortality observed following the blood sampling resulted presumably from failure of such body adjustments.

That failure was also observed in the surviving $C$. saxatilis in the recovery period, but no mortality was observed. Hyperglycemia was observed after 0.5 and $6 \mathrm{~h}$ during recovery (Fig. 1), whereby the specimen is expected to save energy and provide it to vital organs such as brain, heart and muscles in order to withstand the stress (Barton and Iwama, 1991). The concentration of glucose is a key stress indicator (Barton and Iwama, 1991; Tavares-Dias et al., 2001; Urbinati and Carneiro, 2001; Moraes and Martins, 2004). Blood glucose values are high in stress-subjected specimens, and vary according to the received stimuli and the environment (Barcellos et al., 2001; Martins et al., 2004).

Blood glucose levels in situations of distress undergo changes, increasing and returning to default values within $24 \mathrm{~h}$ due to glycogenolytic activity induced by catecholamines, which are produced during exposure to stress in order to restore homeostasis (Mazeaud et al., 1997). However, blood glucose levels remained high up to $24 \mathrm{~h}$ of recovery (Fig. 1a), with an increase of up to $41.86 \%$ (control: $86.2 \mathrm{mg} \mathrm{ml}^{-1}$ ) thereby showing that the agent was very distressful.

An increase in the number of erythrocytes and a reduced volume and weight of corpuscular hemoglobin were observed, but with the same concentration of hemoglobin in cells, allowing compensation in supplying oxygen for the first $0.5 \mathrm{~h}$ of recovery (Barcellos, 2004; Martins et al., 2004). Adrenergic effects as a response to stress, result in splenic

Table 2

$F$ values (Tukey), Means and Standard Deviation (SD) for Weight, Standard Length (SL), total number of Thrombocytes (Tromb.) and Immature Cells (IC) in Crenicichla saxatilis before handling (Control) and $0.5 \mathrm{~h}(30 \mathrm{~min}), 6 \mathrm{~h}(6 \mathrm{~h})$ and $24 \mathrm{~h}(24 \mathrm{~h})$ after combination of short-term handling stress (chasing, capture and air exposure)

\begin{tabular}{llccr}
\hline & Values of $F$ & Mean \pm SD (control) & Mean \pm SD (30 min) & Mean \pm SD (6 h) \\
\hline Weight $(\mathrm{g})$ & $1.58 \mathrm{~ns}$ & $85.2 \pm 61.6$ & $95.2 \pm 58.2$ & - \\
SL $(\mathrm{cm})$ & $0.98 \mathrm{~ns}$ & $16 \pm 4.1$ & $16.6 \pm 3.6$ & $16.7 \pm 3.8$ \\
Tromb. $(\%)$ & $0.11 \mathrm{~ns}$ & $7.4 \pm 6.6$ & $8.7 \pm 8.5$ & $7.1 \pm 5.8$ \\
I. C. $(\%)$ & $0.84 \mathrm{~ns}$ & $4.9 \pm 5.5$ & $3.8 \pm 3.7$ & $6.0 \pm 6.0$ \\
\hline
\end{tabular}


contraction, releasing young erythrocytes into the bloodstream, which contribute to increasing the oxygen transfer to the tissues (Val et al., 2004).

When subjected to stress, fish may develop changes in hemoglobin concentration, hematocrit or number of erythrocytes, suggesting the occurrence of hemoconcentration or hemodilution as a result of osmoregulatory dysfunction (Houston et al., 1996; Tavares-Dias and Ruas De Moraes, 2004). Ringtail pike cichlids were presumably in a state of hemodilution, which may have been needed to provide improved blood fluidity, and, in conjunction with increasing erythrocytes, the heart rate and $\mathrm{MCHC}$ maintenance that could promote the transport of oxygen.

In the present experiment lymphocytopenia and neutrophilia were also observed. The same response was observed in other experiments with fishes exposed to distressing situations (Carneiro and Urbinati, 1998; Martins et al., 2000, 2002; Tavares-Dias et al., 2001; Carneiro et al., 2002). Lymphocytes are the predominant leukocytes in periferic blood of fish except for stress situations (Tavares-Dias and Ruas De Moraes, 2004). The decrease of these cells is due to the presence of glucocorticoids membrane receptors (such as cortisol) blocking their mitotic division. The action of glucocorticoids decreases the number and function, affecting both $\mathrm{T}$ and B lymphocytes, characterizing an immunosuppressive condition, with increased susceptibility to diseases (Barton and Iwama, 1991).

Another alteration in the hematological response was the decrease of total plasma protein after $6 \mathrm{~h}$ in recovery (Fig. 1h). Plasma proteins are involved in fundamental processes such as carrying metabolites, for humoral defense and for coagulation. Their decrease in the bloodstream induces metabolic deficiency, physiological disorders and consequent stress (Satake et al., 2009).

These hematological responses vary depending on the intensity and duration of the stress (Barton and Iwama, 1991), and their return to initial values depends on the exposure time and the type of stress (Moraes and Martins, 2004). Nevertheless, it was not observed in this study because there were variations in the blood values, indicating the permanence at the adaptation stage in the surviving fish.

\section{Conclusions}

The stress response in ringtail pike cichlids in this study was intense and initiated after $0.5 \mathrm{~h}$ during the recovery period. Most of the hematological variables did not return to initial levels after $24 \mathrm{~h}$. The fish subjected to conditions of shortterm handling stress in this study showed hematology variations that are consistent with conditions of distress commonly observed in fisheries and aquaculture, and therefore emphasizes the importance of good management practices in the context of these activities.

\section{References}

Barcellos, L. J. G., 2004: Hematological changes in jundiá (Rhamdia quelen Quoy and Gaimard: Pimelodidae) after acute and chronic stress causes by usual aquacultural management, with emphasis on imunosuppressive effects. Aquaculture 237, 229-236.

Barcellos, L. J. G.; Woehl, V. M.; Wassermann, G. F.; Quevedo, R. M.; Ittzés, I.; Krieger, M. H., 2001: Plasma levels of cortisol and glucose in response to capture and tank transference in Rhamdia quelen (Quoy \& Gaimard), a South American catfish. Aquac. Res. 32, 121-123.

Barton, B. A.; Iwama, G. K., 1991: Physiological changes in fish from stress in aquaculture with emphasis on the response and effects of corticosteroids. Rev. Fish Dis. 1, 3-26.

Barton, B. A.; Haukenes, A. H.; Parsons, B. G.; Reed, J. R., 2003: Plasma cortisol and chloride stress responses in juvenile Walleyes during capture, transport and stocking procedures. N. Am. J. Aquacult. 65, 210-219.

Carneiro, P. C. F.; Urbinati, E. C., 1998: Alterações metabólicas, hematológicas e osmorregulatórias do matrinxã Brycon cephalus causadas pelo estresse de transporte. In: Aqüicultura Brasil 1998. Vol. 2. F. R. de Moraes, P. F. de Castro, E. de Souza Correia (Eds.). Anais Recife, Recife, 609-620.

Carneiro, P. C. F.; Martins, M. L.; Urbinati, E. C., 2002: Effect of sodium chloride on physiological response and the gill parasite, Piscinoodinium sp., in matrinxã, Brycon cephalus (Teleostei: Characidae) subjected to transport stress. J. Aquacult. Trop. 17, 337-348.

Coffigny, R. S.; Perez, M. M.; Valle, F. A., 2005: Caracteristicas morfológicas y histoquímicas de las celulas de la sangre periférica de Oreochromis aureus S. Cichlidae. Revista Eletrônica de Veterinária REDVET. VI, 1-8 outubro. Disponível em: http://www.veterinaria.org/revistas/redvet/n101005.html (ac-cessed on 3 August 2007).

Gama, C. S.; Halboth, D. A., 2003: Ictiofauna das Ressacas das Bacias do Igarapé da Fortaleza e do Rio Curiaú. In: Diagnóstico das Ressacas do Estado do Amapá: Bacias do Igarapé da Fortaleza e Rio Curiaú. L. R. Takiyama and A. Q. Silva (Eds). CPAQ/IEPA e DGEO/SEMA, Macapá-AP, pp. 23-52.

Houston, A. H.; Dobric, N.; Kahurananga, R.; 1996: The nature of hematological response in fish. Fish Physiol. Biochem. 15: 339347

Kori-Siakpere, O., 1985: Hematological characteristics of Clarias isheriensis Sydenham. J. Fish Biol. 27, 259-263.

Kullander, S. O.; Lucena, C. A. S., 2006: A review of the species of Crenicichla (Teleostei: Cichlidae) from the Atlantic coastal rivers of southeastern Brazil from Bahia to Rio Grande do Sul State, with description of three new species. Neotrop. Ichthyol. 4, $127-146$.

Mariano, W. S.; Oba, E. T.; Santos, L. R. B.; Fernades, M. N., 2009: Physiological responses in jeju (Hoplerythrinus unitaeniatus) to atmospheric air exposure. Rev. Brasil. Saúde Prod. Anim. 10, 210-223.

Martins, M. L.; Moraes, F. R.; Moraes, J. R. E.; Malheiros, E. C., 2000: Falhas na resposta do cortisol ao estresse por captura e por carraganina em Piaractus mesopotamicus Holmberg, 1887 (Osteichthyes: Characidae). Acta Sci. 22, 545-552.

Martins, M. L.; Moraes, F. R.; Fujimoto, R. Y.; Nomura, D. T.; Fenerick, J. Jr, 2002: Respostas do híbrido tambacu (Piaractus mesopotamicus Holmberg, 1887 macho x Colossoma macropomum Cuvier, 1818 fêmea) a estímulos simples ou consecutivos de captura. Bol. Inst. Pesca 28, 195-204.

Martins, M. L.; Pilarsky, F.; Onaka, E. M.; Nomura, D. T.; Fenerick, J. Jr; Ribeiro, K.; Myiazaki, D. M. Y.; Castro, M. P.; Malheiros, E. B., 2004: Hematologia e resposta aguda em Oreochromis niloticus (Osteichthyes: Cichlidae) submetida aos estímulos único e consecutivo de estresse de captura. Bol. Inst. Pesca 30, 71-80.

Mazeaud, M. M.; Mazeaud, F.; Donaldsom, E. M., 1997: Primary and secondary effects of stress in fish: Some new data with a general review. Trans. Am. Fish. Soc. 106, 201-212.

Moraes, F. R.; Martins, M. L., 2004: Condições predisponentes e principais enfermidades de teleósteos em piscicultura intensiva. In: Tópicos Especiais em Piscicultura de Água Doce Tropical Intensiva. J. E. P. Cyrino, E. C. Urbinati, D. M. Fracalossi, N. Castagnolli (Eds.). Editora. TecArt., São Paulo, pp. 343-386. 
Ozório, R. O. A.; Avnimelech, Y.; Castagnolli, N., 2004: Sistemas intensivos fechados de produção de peixes. In: Tópicos Especiais em Piscicultura de Água Doce Tropical Intensiva. J. E. P. Cyrino, E. C. Urbinati, D. M. Fracalossi, N. Castagnolli (Eds.). Editora. TecArt., Jaboticabal, pp. 7-24.

Ranzani-Paiva, M. J. T.; Eiras, A. C., 1992: Células sanguíneas e contagem diferencial de leucócitos de 13 espécies de teleósteos do Rio Paraná-PR. In: Simpósio Brasileiro de aqüicultura, 7, encontro brasileiro de patologia de organismos aquáticos, Vol. 2. Simbraq (Ed.). Abraq, Peruíbe, pp. 173-182.

Ranzani-Paiva, M. J. T.; Rodrigues, E. L.; Eiras, A. C.; Campos, B. E. S., 2003: Differential leucokocyte counts in 'dourado', Salminus maxillosus Valenciennes, 1840, from the Mogi-Guaçu River, Pirassununga, São Paulo. Braz. J. Vet. Res. Anim. Sci. 63, $517-525$.

Satake, M. M.; Hisano, H.; Pádua, S. B.; Tavares-Dias, M., 2009: Relação peso-comprimento, fator de condição e parâmetros hematológicos de Dourado Salminus brasiliensis cultivado em condições experimentais. Bol. Pesquisa e Desenvolvimento. Embrapa Agropecuário Oeste. ISSN 1679-0456, junho.

Selye, H., 1950: Stress and the general adaptation syndrome. Brit. Med. J. 1, 1383-1392.

Sumpter, J. P.; Pottinger, T. G.; Ran-Weaver, M.; Campbell, P. M., 1994: The wide-ranging effects of stress in fish. In: Perspectives in comparative Endocrinology. K. G. Davey, R. E. Peter, S. S. Tobe (Eds.). National Research Council of Canada, Toronto, Ontario, pp. 535-538.

Takahashi, L. S.; Abreu, J. S.; Biller, J. D.; Urbinati, E. C., 2006: Efeito do ambiente pós-transporte na recuperação dos indicadores de estresse de pacus juvenis, Piaractus mesopotamicus. Acta Sci. Anim. Sci. 28, 469-475.

Tavares-Dias, M., 2003: Variáveis Hematológicas de Teleósteos Brasileiros de Importância Zootécnica. Centro de Aqüicultura, Universidade Estadual Paulista, São Paulo, Dissertação de Mestrado.

Tavares-Dias, M.; Faustino, C. D., 1998: Parâmetros hematológicos da tilápia-do-Nilo Oreochromis niloticus (Cichlidae) em cultivo extensivo. Ars Vet. 14, 254-263.

Tavares-Dias, M.; Ruas De Moraes, F., 2004: Hematologia de Peixes Teleósteos. Ribeirão Preto, São Paulo.
Tavares-Dias, M.; Martins, M. L.; Moraes, F. R., 2000: Características hematológicas de teleósteos Brasileiros. V. variáveis de piauçu Leporinus macrocephalus Garavelos \& Britski, 1988 (Anostomidae). Naturalia 25, 39-52.

Tavares-Dias, M.; Sandrim, E. F. S.; Moraes, F. R.; Carneiro, P. C. F., 2001: Physiological responses of 'tambaqui' Colossoma macropomum (Characidae) to acute stress. Bol. Inst. Pesca 27, 43-48.

Tavares-Dias, M.; Melo, J. F. B.; Moraes, G.; Moraes, F. R., 2002: Características Hematológicas de Teleósteos Brasileiros. IV. Variáveis de Jundiá Rhamdia quelen (Pimelodidae). Rev. Ciência Rural 32, 693-698.

Upton, K. R.; Riley, L. G., 2012: Acute stress inhibits food intake and alters ghrelin signaling in the brain of tilapia (Oreochromis mossambicus). Domest. Anim. Endocrinol. 44, 157-164.

Urbinati, E. C.; Carneiro, P. C. F., 2001: Metabolic and hormonal responses of matrinxã, Brycon cephalus (Teleost: Characidae) to transport stress under influence benzocaine. J. Aquacult. Trop. 16, 75-85.

Urbinati, E. C.; Carneiro, P. C. F., 2004: Prática de manejo e estresse dos peixes em piscicultura. In: Tópicos Especiais em Piscicultura de Água Doce Tropical Intensiva. J. E. P. Cyrino, E. C. Urbinati, D. M. Fracalossi, N. Castagnolli (Eds.). Editora TecArt., Jaboticabal, SP, pp. 171-193.

Val, A. L.; Silva, M. N. P.; Val, V. M. F. A., 2004: Estresse em peixes Ajustes fisiológicos e distúrbios orgânicos. In: Sanidade de Organismos Aquáticos. M. J. T. Ranzani-Paiva, R. M. Takemoto, M. Lizama and A. P. de los (Eds). Editora Varela, São Paulo, pp. 75-88.

Val, A. L.; Menezes, A. C. L.; Ferreira, M. S.; Silva, M. N. P.; Araújo, R. M.; Almeida-Val, V. M. F., 2006: Estresse em peixes: respostas integradas para a sobrevivência e a adaptação. In: Sanidade de Organismos Aquáticos no Brasil. A. T. Silva-Souza (Ed.). Abrapoa. Maringá-PR, Maringá, pp. 211-228.

Vallada, E. P., 1999: Manual de Técnicas Hematológicas. Editora Atheneu, São Paulo, pp. 104.

Author's address: Rodrigo Yudi Fujimoto, Embrapa Tabuleiros Costeiros Av. Beira mar 3250, CEP 49025-040, Aracaju - Sergipe, Brazil. E-mail: ryfujim@hotmail.com 